\title{
IMMUNOLOGICAL STUDIES OF THE RAT UTERINE FLUID PEPTIDASE
}

\author{
M. S. JOSHI AND I. M. MURRAY \\ Department of Anatomy, Downstate Medical Center, Brooklyn, New York, U.S.A.
}

(Received 14th May 1973)

\begin{abstract}
Summary. Endopeptidase isolated from the uterine fluid of oestrous rats was used to immunize rabbits. Immunoelectrophoresis of whole uterine fluid, purified uterine fluid peptidase and blood serum indicated that the peptidase is unique to uterine secretion and is not found in blood. The immunofluorescent protein tracing was carried out in frozen sections of the reproductive organs of immature rats, immature rats given oestrogen, mature cycling, pregnant and pseudopregnant rats. Specific immunofluorescence was observed in the luminal epithelium of the proximal portion of the oviduct of immature rats and mature rats irrespective of the stage of the cycle. The luminal epithelium and the epithelium of the endometrial glands of uteri obtained from pro-oestrous and oestrous rats showed the presence of the specific peptidase. The luminal and glandular epithelium of immature rat uterus showed the appearance of endopeptidase $40 \mathrm{hr}$ after the injection of oestradiol. The presence of the uterine fluid peptidase was observed in the endometrial glands on Day 5 of pregnancy. Immunofluorescence analysis of ejaculated spermatozoa recovered from the uterus soon after mating showed accumulation of the enzyme at the head region.
\end{abstract}

\section{INTRODUCTION}

Accumulation of uterine fluid during the pro-oestrous stage in the rat has been demonstrated by Long \& Evans (1922) and Warren (1938). Armstrong (1968) investigated the rôle of oestrogen and progesterone on the accumulation of this fluid. The analyses of the various chemical constituents of this oestrous fluid and of the uterine washing at different stages of the oestrous cycle have been carried out by Junge \& Blandau (1958), Ringler (1961), Albers \& Castro (1961), Albers, Bedford \& Chang (1961), Heap \& Lamming (1962) and Kunitake, Nakamura, Wells \& Moyer (1965). Thus, sufficient evidence has been provided that the uterine fluid is a product of active secretion and not merely a transudate from the vascular system. The exact rôle of this uterine fluid in reproduction has not been understood.

We have isolated and characterized an endopeptidase from uterine luminal fluid obtained from pro-oestrous rats and from immature rats treated with oestrogen (Joshi, Yaron \& Lindner, 1970). This enzyme, when incubated with epididymal spermatozoa of rats or mice, brought about the separation of the 
head from the mid-piece-tail segment and differed considerably from the peptidases identified by previous workers. The present work was undertaken to locate the enzyme in the female reproductive tract during different stages of the oestrous cycle and pregnancy by using an immunofluorescence technique.

\section{MATERIALS AND METHODS}

Wistar rats from Carworth Farms were used in all of the studies. Daily vaginal smears were recorded and the uterine luminal fluid was aspirated from the pro-oestrous rat between 20.00 and 22.00 hours. Ovariectomized rats were given an intramuscular injection of $50 \mu \mathrm{g}$ oestradiol- $17 \beta$ in $0.1 \mathrm{ml}$ sesame oil per day for 3 days and the rats were killed $24 \mathrm{hr}$ after the last injection and the uterine luminal fluid was collected. The endopeptidase was isolated from the luminal fluid by the method described by Joshi et al. (1970) using a Sephadex G-200 column. One millilitre of the concentrated purified fraction or concentrated whole uterine fluid ( 1 to $2 \mathrm{mg}$ protein $/ \mathrm{ml}$ ) was mixed with an equal volume of Freund's complete adjuvent and injected intradermally at ten to fifteen sites on the back of the rabbit. Six weeks later, a booster dose of $0.6 \mathrm{ml}$ of the concentrated antigen was injected intravenously through the marginal ear vein. The antiserum was collected 10 days after the second injection.

The immunoelectrophoresis was performed according to Grabar (1964) in $0.05 \mathrm{M}$-veronal buffer ( $\mathrm{pH} \mathrm{8.4)} \mathrm{at} 100 \mathrm{~V}$ for $1 \mathrm{hr}$. The microplates were developed at $37^{\circ} \mathrm{C}$ for 2 days after adding $50 \mu \mathrm{l}$ of the antiserum to the central groove. Photographs of the precipitin arcs were taken before and after staining with $0.005 \%$ nigrosin.

The globulin fraction obtained from the antiserum and from normal rabbit serum after $40 \%$ ammonium sulphate saturation was conjugated with fluorescene isothiocyanate (FITC) and the fluorescene which had not reacted was removed by passing the conjugate through Sephadex G25 and DEAE columns (Nairn, 1969). The protein estimations were carried out according to Lowry, Rosebrough, Farr \& Randall (1951).

The antisera were absorbed by the addition of adequate amounts of freezedried female rat serum until no precipitate was obtained by further addition.

For fluorescent protein tracing in tissues, all animals were killed between 10.00 and 11.00 hours. The tissues were cut in $1-$ to $2-\mathrm{cm}$ portions and quickly frozen in isopentane which had been previously cooled with liquid nitrogen. Sections ( 5 to $7 \mu \mathrm{m}$ ) were cut in a cryostat and fixed in $95 \%$ ethanol for $1 \mathrm{hr}$. The fixative was washed in saline and processed for fluorescent protein tracing according to the method of Nairn (1969). Two control sections were also processed with every experiment. Control sections were stained with normal rabbit globulin conjugated with FITC. The other control sections were incubated with unlabelled immunoglobulin before incubating with immunoglobulin-FITC. Fluorescence was observed on a Zeiss microscope using a mercury lamp with BG12 excitation filter and with appropriate secondary filters. Alternate sections of the tissue were stained with haematoxylin and cosin.

Three immature 22-day-old rats were given an intramuscular injection of $0.1 \mathrm{ml}(10 \mu \mathrm{g})$ oestradiol- $17 \beta$ in sesame oil, while the control animals received 


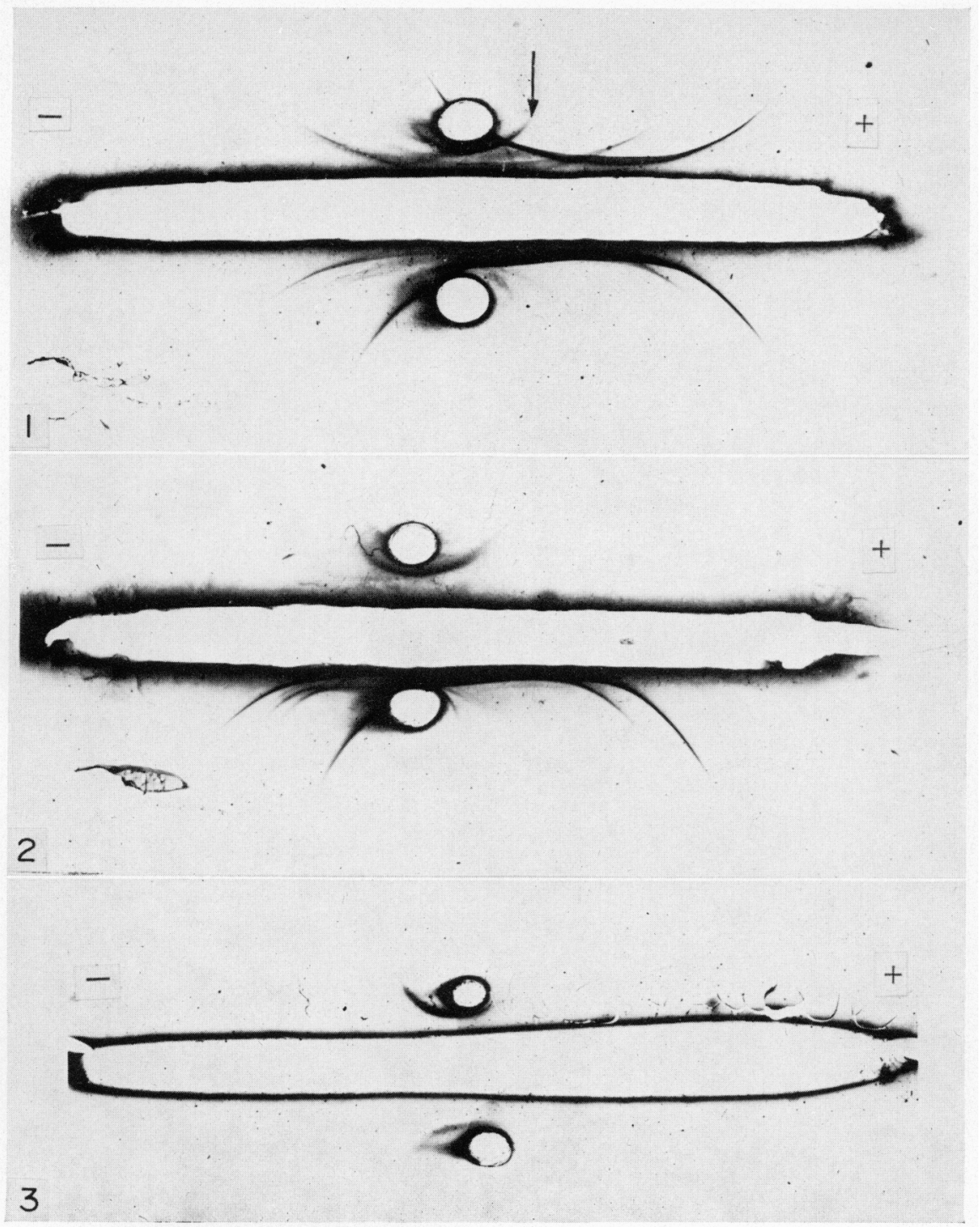

The immunoelectrophoretic analysis of:

Fig. 1. Rat whole uterine fluid (upper well) and blood serum (lower well) developed with rabbit antiserum to the whole uterine fluid. The arrow indicates the precipitin line specific to the uterine fluid peptidase.

FIG. 2. Purified uterine fluid peptidase (upper well) and blood serum (lower well) developed with antiserum to whole uterine fluid.

FIG. 3. Purified uterine fluid peptidase (upper well) and whole uterine fluid (lower well) developed with antiserum to whole uterine fluid absorbed with blood serum.

(Facing p. 362) 


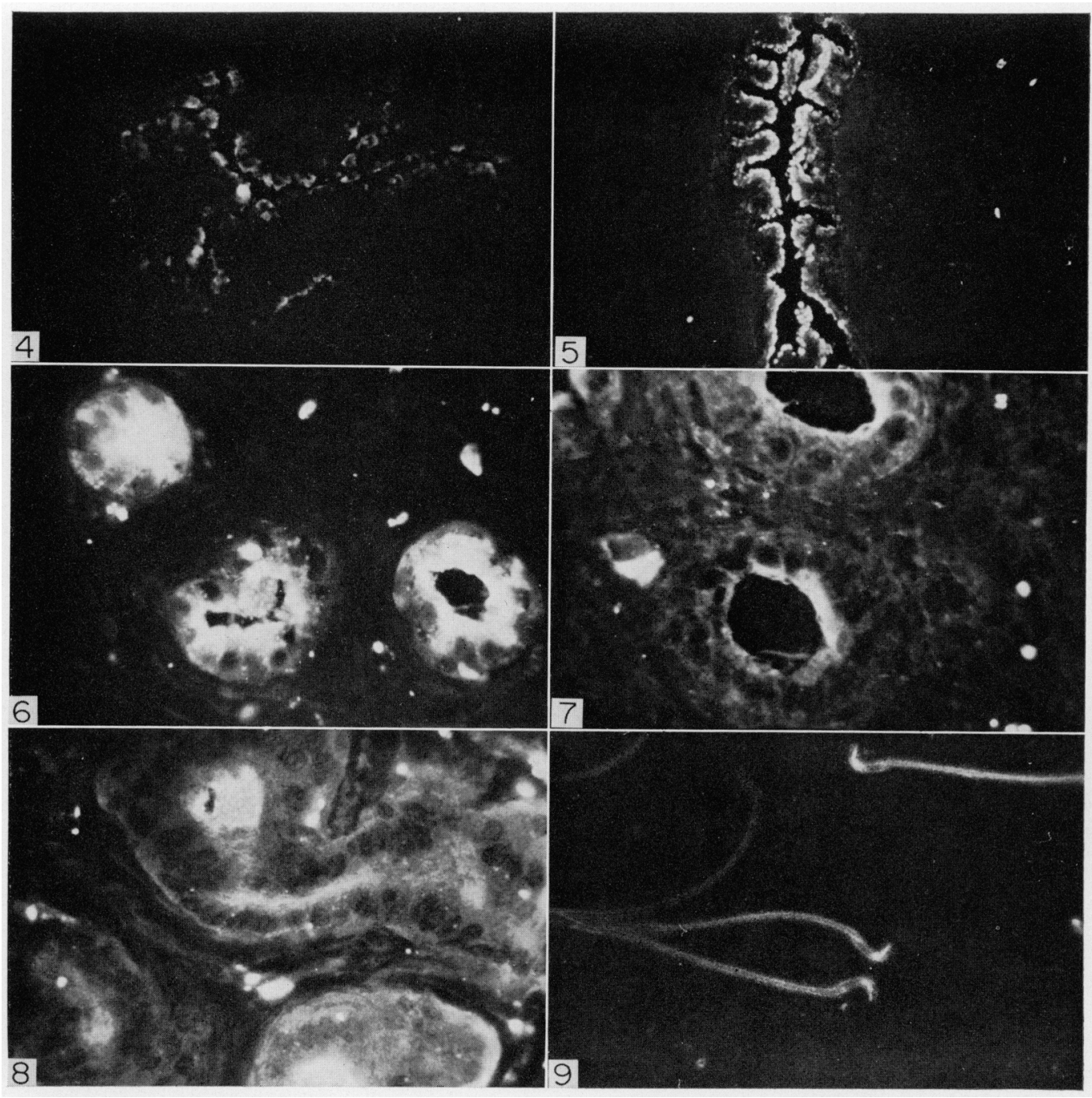

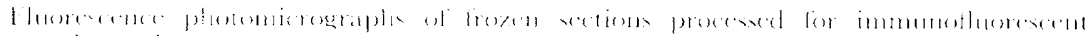

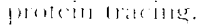

l'u, t. ( )

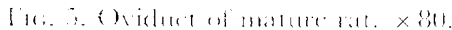

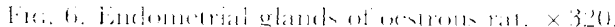

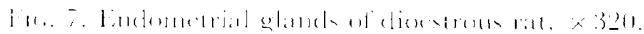

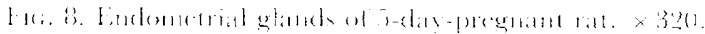

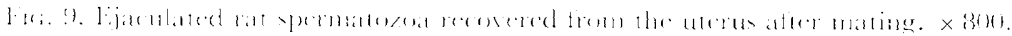


the same amount of oil. The control and the experimental rats were killed at 16,40 and $64 \mathrm{hr}$ after the injection, and the uterus and oviduct were processed for fluorescent protein tracing. The pseudopregnancy was induced by mating the female with a vasectomized male. Ejaculated spermatozoa were aspirated from the uterus within $2 \mathrm{hr}$ of mating; smears were fixed in $95 \%$ ethanol and processed for fluorescent protein tracing.

\section{RESULTS}

\section{Immunoelectrophoresis}

The immunoelectrophoresis of the whole uterine fluid showed at least five common antigens with rat serum (Pl. 1, Fig. 1). The whole uterine fluid contained an additional precipitin arc which corresponded to the precipitin arc obtained after immunoelectrophoresis of the purified uterine fluid peptidase (Pl. 1, Fig. 2, top well). The antiserum to the whole uterine secretion retained the antibody to the uterine fluid peptidase after complete absorption with rat blood serum (Pl. 1, Fig. 3).

\section{Immunofluorescent protein tracing in immature rats}

The frozen sections of the ovary, vagina and uterus did not show any immunofluorescence but the luminal epithelial cells of the proximal portion of the oviduct exhibited strong immunofluorescence (Pl. 2, Fig. 4). The uterus showed the presence of uterine fluid peptidase in the luminal and glandular epithelium $40 \mathrm{hr}$ after a single injection $(10 \mu \mathrm{g})$ of oestradiol.

\section{Immunofuorescent protein tracing in cycling, pseudopregnant, and pregnant rats}

The uterine luminal epithelium and the epithelium of the endometrial glands during pro-oestrus or oestrus contained specific immunofluorescent granules (Pl. 2, Fig. 6). Very scanty fluorescence was observed in a similar region of the uterus during dioestrus (Pl. 2, Fig. 7). The luminal epithelium of the proximal portion of the oviduct of rats in all stages of the oestrous cycle showed strong immunofluorescence (Pl. 2, Fig. 5). Sections of the uterus on Day 5 or Day 6 of pregnancy or pseudopregnancy (the presence of spermatozoa or a vaginal plug $=$ Day 1 ) showed specific fluorescence in the endometrial glands (Pl. 2, Fig. 8) but not in the uterine luminal epithelium. Sections of the ovary, vagina, pancreas, liver, spleen and intestine did not show the presence of the endopeptidase.

Ejaculated spermatozoa obtained from the uterus within $2 \mathrm{hr}$ of ejaculation showed the presence of the uterine fluid peptidase near the acrosomal region (Pl. 2, Fig. 9). Epididymal spermatozoa or washed ejaculated spermatozoa did not exhibit this immunofluorescence.

\section{DISCUSSION}

Immunoelectrophoretic analyses and immunofluorescent protein tracing has provided evidence to show that uterine fluid peptidase is unique to the uterus and is not found in blood or other tissues. The appearance of the peptidase in 
the uterine lumen of immature and ovariectomized rats treated with oestradiol indicated that this enzyme is oestrogen dependent. The presence of large numbers of immunofluorescent granules in the glandular epithelium at the peak oestrous stage suggests that the uterine glands elaborate the enzyme during oestrogen dominance and contribute to the uterine secretion. Between Day 1 and Day 10 of pregnancy or pseudopregnancy, the uteri showed the appearance of the uterine fluid peptidase in the uterine glands on Day 5 and Day 6. The presence of the enzyme during this period may be influenced by the oestrogen surge which takes place on Day 4 of pregnancy (Shaikh \& Abraham, 1969; Waynforth, Pope \& Hosking, 1972). The presence of immunofluorescent granules in the oviducal epithelium and their absence in the uterine epithelium of immature rats is puzzling. One possible explanation is that the oviduct may be more sensitive to the amounts of oestrogen produced by the immature rat ovary (Cierciorowska \& Russfield, 1968).

The oestrogen secreted by the ovary during the oestrogen surge is known to be necessary for sensitization of the uterus for decidualization and implantation reaction (Shelesnyak, Kraicer \& Zeilmaker, 1963). The dissolution of the zona pellucida and implantation are closely connected events which may involve participation of enzyme(s). The mouse blastocysts shed their zona pellucida shortly before they attach themselves to the uterine epithelium and the loss of the zona pellucida is delayed for a long period when ovariectomy is performed early in pregnancy (Orsini \& McLaren, 1967). These authors have suggested that an hormonally determined uterine factor may be acting on the zona pellucida to weaken it. It seems likely that the oestrogen-dependent uterine fluid peptidase contributed by the oviducal and uterine epithelium may play a rôle in the lysis of the zona pellucida of the blastocyst.

The ejaculated spermatozoa aspirated from the rat uterus have a distinct gel coating of seminal plasma constituents. The gelation of the seminal plasma constituents is induced by bicarbonate present in the uterine fluid (Joshi, Yaron \& Lindner, 1972). This coating probably serves to inhibit the decapitating activity of the uterine fluid peptidase (Joshi et al., 1970). The uterine fluid peptidase strongly adheres to the ejaculated spermatozoa, especially in the acrosomal region (Pl. 2, Fig. 9). Proteolytic activity has been demonstrated around the acrosome, particularly at the convexity of the head of the rat epididymal spermatozoon (Benitez-Bribiesca \& Velazquez-Meza, 1972). The uterine fluid peptidase seems to accumulate at the concavity of the head. It is possible that the uterine fluid peptidase adhering to the spermatozoa may be involved in ovum penetration or assist in capacitation of spermatozoa in the uterus.

\section{REFERENCES}

Albers, H. J., Bedford, J. M. \& Ghang, M. C. (1961) Uterine peptidase activity in the rat and rabbit during pseudopregnancy. Am. F. Physiol. 201, 554.

Albers, H. J. \& CAstro, M. Neves E (1961) The protein components of rat uterine fluid. Fert. Steril. 12,142 .

Armstrong, D. T. (1968) Hormonal control of uterine lumen fluid retention in the rat. Am. F. Physiol. 214,764 .

Benitez-Bribiesca, L. \& VelazQuez-Meza, S. (1972) Cytochemical demonstration of proteolytic activity of human and rat spermatozoa. J. Reprod. Fert. 29, 419. 
Cierciorowska, A. \& Russfield, A. B. (1968) Determination of estrogenic activity of the immature rat ovary. Archs Path. 85, 658.

GraBar, P. (1964) The immuno-electrophoretic method of analysis. In Immuno-electrophoretic Analysis. Application to Human Biological Fluids, p. 26. Eds. P. Grabar and P. Burtin. Elsevier Publishing Company, New York.

Heap, R. B. \& Lamming, G. E. (1962) The influence of ovarian hormones on some chemical constituents of the uterine washings of the rat and rabbit. F. Endocr. 25, 57.

Joshi, M. S., YARon, A. \& Lindner, H. R. (1970) An endopeptidase in the uterine secretion of the proestrous rat and its relation to a sperm decapitating factor. Biochem. biophys. Res. Commun. $38,52$.

Joshi, M. S., Yaron, A. \& Lindner, H. R. (1972) Intrauterine gelation of seminal plasma constituents in the rat after coitus. F. Reprod. Fert. 30, 27.

Junge, J. M. \& Blandau, R. J. (1958) Studies on the electrophoretic properties of the cornual fluids of rats in heat. Fert. Steril. 9, 353.

Kunitake, G. M., Nakamura, R. M., Wells, B. G. \& Moyer, D. L. (1965) Studies on uterine fluid. I. Disc electrophoretic and disc-gel Ouchterlony analyses of rat uterine fluid. Fert. Steril. 16, 120.

Long, J. A. \& Evans, H. M. (1922) The oestrous cycle in the rat and its associated phenomena. Mem. Univ. Calif. 6, 24.

Lowry, O. H., Rosebrough, N. J., FArR, A. L. \& Randali, R. J. (1951) Protein measurement with the Folin phenol reagent. F. biol. Chem. 193, 265.

NAIRN, R. C. (1969) Immunological tracing: general consideration. In Fluorescent Protein Tracing, p. 111. Ed. R. C. Nairn. Williams \& Wilkins, Baltimore.

Orsint, M. W. \& McLaren, A. (1967) Loss of the zona pellucida in mice, and the effect of tubal ligation and ovariectomy. $\mathcal{F}$. Reprod. Fert. 13, 485.

Ringler, I. (1961) The composition of rat uterine luminal fluid. Endocrinology, 68, 281.

Shaikh, A. A. \& Abraham, G. E. (1969) Measurement of estrogen surge during pseudopregnancy in rats by radioimmunoassay. Biol. Reprod. 1, 378.

Shelesnyak, M. C., Kraicer, P. F. \& Zeilmaker, G. H. (1963) Studies on the mechanism of decidualization. I. The estrogen surge of pseudopregnancy and progravidity and its role in the process of decidualization. Acta endocr., Cophenh. 42, 225.

Warren, M. R. (1938) Observations on the uterine fluid of the rat. Am. F. Physiol. 122, 602.

WAynforth, H. B., Pope, G. S. \& Hosking, Z. D. (1972) Secretion rates of oestrogens into the ovarian venous blood of pregnant rats. F. Reprod. Fert. 28, 191. 